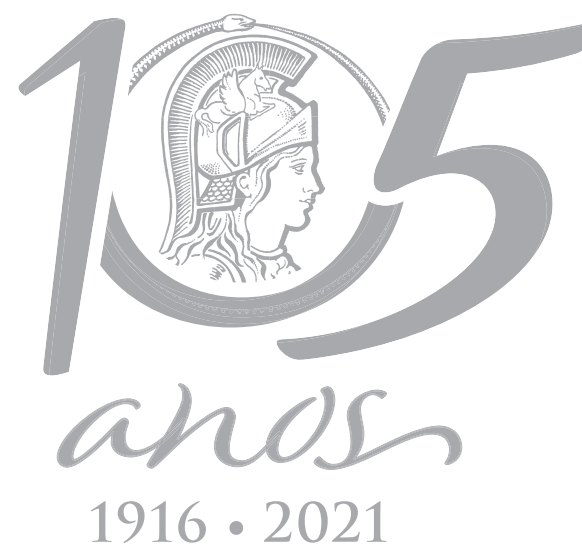

\title{
The Neglected Role of Education in Brazilian Research Regarding Nuclear Theme versus Scientific and Technological Knowledge, Perception and Risk Communication
}

\author{
RAFFAELA M. AYLLÓN, ALEX A. CASTRO, FERNANDA C. ROMERO, LUIZ O. \\ CERQUEIRA LEITE \& LUCIANA A. FARIAS
}

\begin{abstract}
Studies of risk perception and risk communication concerning the nuclear area are quite common in scientific literature. However, though numerous studies on this topic point to the importance of scientific and technological knowledge in facilitating the reduction of perceived risks, there are few papers that effectively discuss the role of education in risk communication on the subject, particularly in Brazil. The objective of the present work was to reflect on this problem by analyzing the results obtained from two case studies on the implementation of the Brazilian Multipurpose Reactor, in the city of Iperó, in the state of São Paulo, Brazil. As was verified in the investigation, most participants of the study had high perception of risk with respect to the implementation of the reactor. Nevertheless, although important in the project of the reactor implementation, it was verified that the state, municipal and community schools of the city of Iperó had not participated, in the public hearings nor had they discussed the issue inside the school community, until the moment of the research.
\end{abstract}

Key words: education, implementation of reactor, nuclear technology, perception of risk, scientific knowledge.

\section{INTRODUCTION}

According to Lima et al. (2011) the so-called belle époque occurred in Europe in the late nineteenth and early twentieth century. During that period, science was prominent due to the new inventions made or those that gained unprecedented popularity in the period like, the telephone, cinema, automobile, airplane, radio, among several others. With the discovery of radioactivity, the scenario was not very different, and this knowledge led to not only a scientific and social revolution, but also birthed one of the most controversial "love and hate" relationships in the history of contemporary science.
It is evident that the nuclear sector has been more successful in the academy than socially or politically. Historically, events such as the dropping of atomic bombs in the cities of Hiroshima and Nagasaki in 1945, as well as the nuclear accident in Chernobyl in 1986, heavily influenced the negative image of nuclear technology in popular psyche and contributed to the transformation of popular perception of risk. Therefore, several studies of perception and communication recur in the nuclear scientific literature, since a high perception of risk among the population may result in a significant social cost, affecting the area revenues, costs and financial conditions, as discussed by Huhtala \& Remes (2017). 
Despite the socio-environmental damage undergone by areas affected by major negative events, nuclear technology is very important, providing numerous benefits to the population, such as in health. These positive aspects may be maintained and increased. However, in order to do so, investments are necessary, including those for the implementation of new nuclear reactors for research or for energy production. To be successful in implementing and accepting new technologies, positive public opinion is fundamental and even though there is no consensus (Wu 2017), studies highlight the importance of knowing different variables directly related to the perception of risk, especially public opinion as well as the levels of public knowledge on a particular subject of interest (Frantál \& Malý 2017, Zhu et al. 2016, Yim \& Vaganov 2003).

Regarding scientific and technological knowledge, it is important to highlight the role of an effective education program. Guimarães (2015) argues that there is an increasing number of energy production nuclear facilities and to boost the development of this sector, two important aspects should be considered: CAPEX and public acceptance. The author states that public opinion and political support for nuclear technology are local and variable across countries. Social support should not be restricted to just associated jobs, it should consider familiarity with the technology and the everyday life of the place. He highlights that in developing countries, it is necessary to have a certain educational level to increase understanding on the subject as well as to improve nuclear safety. Thus, an alternative would be education and communication directed towards certain groups, such as young people and schools, especially as this audience has hardly assimilated the prejudices related to this technology unlike previous generations.
With this perspective, the objective of the present work was to identify, analyze and understand the risk perception concerning the implementation of the Brazilian Multipurpose Reactor (BMR), in the city of Iperó, state of São Paulo, Brazil. To this end, two case studies were carried out, one focused on city residents and another on teachers from a public school in the same location.

\section{MATERIALS AND METHODS}

This article is a synthesis of two concomitant works by the group at the Federal University of São Paulo. The first one was developed as part of a master's project in the Postgraduate Program in Integrated Environmental Analysis and aimed to investigate the perception of risk and social representations of the municipality population neighboring the BMR, considering the various dimensions of the issue. The second case study focused on the participation of the local schools in the debates regarding the BMR, developed in the scope of the conclusion work of the Bachelor of Science course. The proposal was qualitative and quantitative exploratory (Gil 2002) in the form of a case study, understood here as an "empirical investigation that investigates a contemporary phenomenon (the case) in depth and in its real-world context, especially when the boundaries between phenomenon and context are not clearly evident" (Yin 2015).

\section{The Brazilian Multipurpose Reactor}

Brazilian nuclear medicine has a share of $4.4 \%$ of the world market to the nuclear area, and this is proportionally inferior to many countries, in per capita terms, such as Argentina (2.6 times lower) and the United States (6.2 times lower), thereby underlining the inevitable need to grow in the area, as Aquino \& Vieira (2010) explain. 
Another important fact to be mentioned here refers to a discussion held in 2014, in which a possible deficiency in the production and import of molybdenum-99 was predicted in 2016 due to its use as a raw material in the manufacture of technetium-99. These two facts brought to light the urgent need in Brazil to find alternatives to produce radioisotopes, particularly molybdenum-99.

Hence, in May 2010, the Ministry of Science and Technology and Innovation released funds for the elaboration of the basic project of BMR (Aquino \& Vieira 2010). The main objective of the project is to produce radioisotopes, radioactive sources and nuclear fuels, carrying out scientific and technological research in the area.

So that the employment of the BMR may actually occur, a series of procedures for approval and implementation of the project should be carried out in accordance with Brazilian legislation, including the need to promote public hearings to present environmental studies, publicize the project and to have clarification of doubts about the installation of the reactor, according to Brazilian law 6.938/81 and Conselho Nacional do Meio Ambiente (National Environment Council) (CONAMA) Resolution 001/86 (Conama 1986). To comply with Brazilian legislation, there were three public hearings in 2013, one in each municipality that will be directly impacted by the presence of the BMR, which are: Iperó, the site of the future installation, São Paulo, the capital of the state and Sorocaba, in the neighboring municipality of Iperó.

Despite the scientific, technological and social importance, many residents of Iperó stood against the project. This is not an isolated Brazilian problem, since many studies in different countries whose objective was to know the Risk Perception of the general population on the nuclear theme, have highlighted the same problem (Yim \& Vaganov 2003, Pidgeon 1988, Pidgeon et al. 2008).

\section{Participating public and data collection}

Data collection was carried out between April 2015 and January 2016, totalling 30 visits to the municipality.

In the study with the municipality population, ( $N=198)$ semi-structured questionnaires were used to assess the local population's perception of risk. At that stage, the participants were approached in commercial places, health centers, the street or their residences, where participants of the study were young people as old as 18 years as well as adults, both men and women, who were residents and workers at Iperó. Individuals from all districts of the municipality, both rural and urban areas, participated in the research. The mean age of participants was 37 years, 55\% female and 45\% male. Participants were predominantly urban dwellers representing $76 \%$ of total share.

In the study with local schools, all State and Municipal schools in the city of Iperó (totalizing 11 schools) were visited, with a semi-structured questionnaire applied to the Coordinators, Principals, Vice-Principals and Teachers of the institutions, with the aim of investigating the knowledge of participants about the nuclear issue in general, as well as the school participation in the debates regarding the BMR implementation in the municipality. At that stage, a total of 62 questionnaires were answered, from which 68\% corresponded to the female sex, 32\% to males; the average age for females was approximately 40 years old, while for male participants was 37 years old.

\section{Results analysis}

To evaluate data obtained from the questionnaires, under the quantitative 
methodology approach, data were organized in charts and tables to allow comparison of results.

For qualitative analysis on the other hand, a content analysis was performed as per the model of Bardin (1994).

Content analysis, as well as a speech analysis, is a qualitative research methodology that may be evaluated from theories aiming at a more efficient analysis of the speeches or writing of social actors. In addition, the Likert scale was used, using the scale of 1 to 7 , in a large part of the questionnaire, with the objective of verifying the agreement and disagreement on the subject addressed (Dalmoro \& Vieira 2013).

\section{RESULTS AND DISCUSSION}

\section{Results from the study with the municipality population}

Regarding the level of education in this study, it was observed that $39 \%$ of the participants had higher education, complete or incomplete, $6 \%$ had a postgraduate degree, 39\% had attended high school, $15 \%$ had elementary school education while the remaining did not answer.

According to the Fundação Sistema Estadual de Análise de Dados Estatísticos (SEADE 2016), the population aged 18 to 24 years old, with at least a complete secondary education, represents $47 \%$ of the Iperó population and, through the analysis of 2010 census of the Instituto Brasileiro de Geografia e Estatística (Brazilian Institute of Geography and Statistics) (IBGE), it was possible to verify the low educational level of the Iperoense 1 population, when compared to the state of São Paulo, as well as when compared to the neighbouring municipality, Sorocaba, which presented a rate of $66 \%$ of the population between 18 and 24 years of age with complete secondary education (IBGE 2010). According to

\footnotetext{
People from Iperó.
}

some authors, this variable seems to influence the perception of risk (Frantál \& Malý 2017, Zhu et al. 2016, Yim \& Vaganov 2003).

While it is possible to verify that perception of risk in relation to the facility is high, it is important to note however that most participants did not have an aversion to the BMR because they believed that the country would benefit from its arrival. In light of this fact, increasing the perception of the population's benefits may be the alternative to reduce the perception of risks of the residents of Iperó regarding the presence of the reactor.

On the other hand, when asked if the implementation of the BMR would be a reason of pride for the municipality, different opinions arose. At first, the feeling of pride seemed secondary and vary individually compared to other basic visceral expressions, such as fear, disgust, sadness, or joy. However, studies conducted by Tracy \& Robins (2014) reflect that pride deals with a self-conscious emotion, reflecting how individuals feel about themselves or something and therefore, has an important role in the social network. According to the authors, pride is the strongest sign of status we know among emotions, stronger than an expression of happiness, contentment as well as among others.

Another feeling related to the place of implementation of the BMR is the topophyllic one, which according to Tuan (1980) is the perception of the place from its affective dimension, considering the environment, visual and relations of familiarity with the place.

Within this perspective, as shown in Figure 1 , although a group visualizes benefits regarding the implantation of the BMR, this positive aspect is still seen as a future possibility and not reality. This in turn, could justify the predominance of the feeling of non-pride and consequent highrisk perception. 


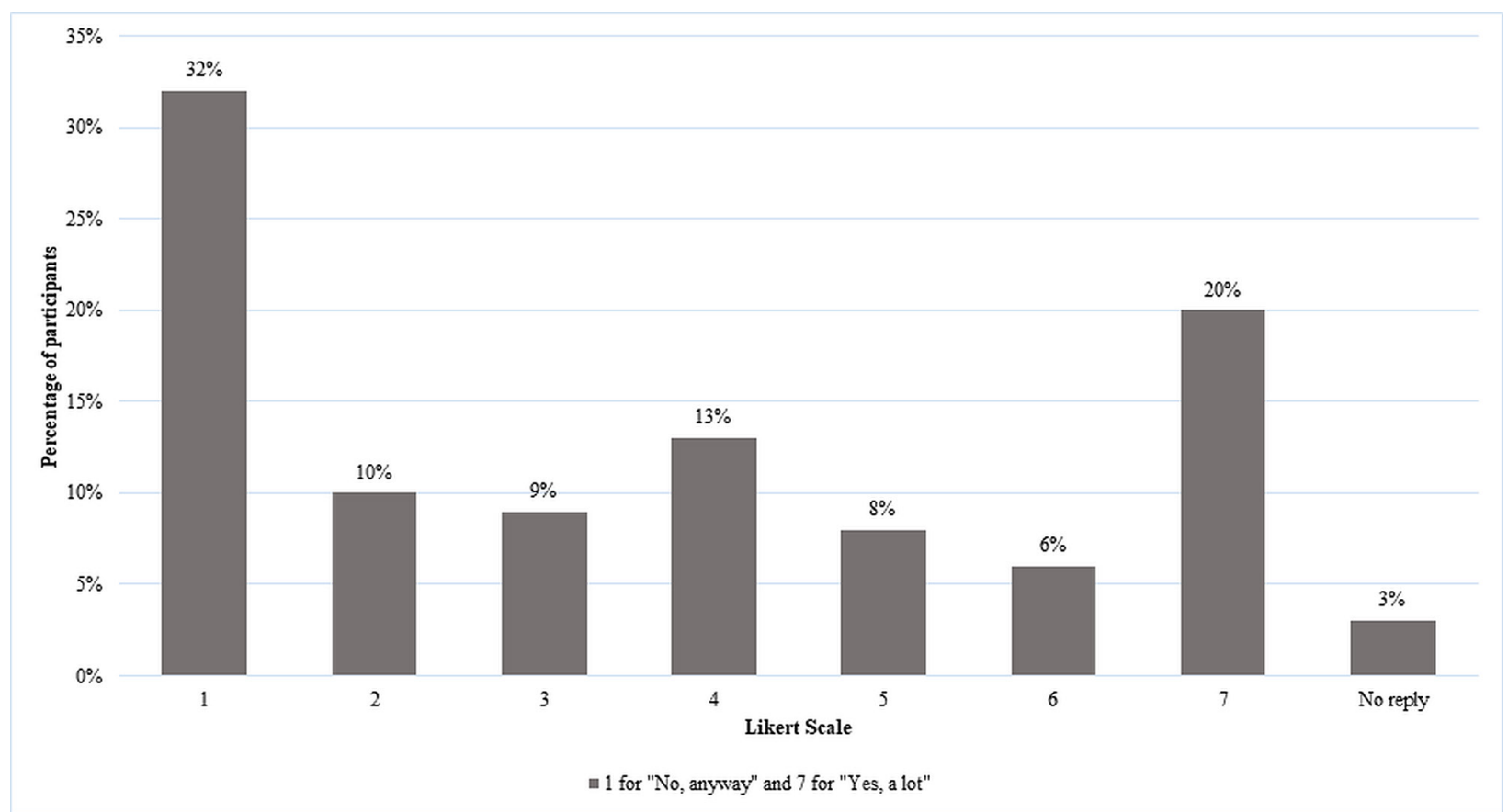

Figure 1. Participants' evaluation of the feeling of pride related to the BMR, using the Likert scale.

Finally, analyzing the results for the justifications given, in general terms the participants considered that the implementation of the BMR may cause some type of risk to the municipality, mainly related to "bombs" and "accidents" which contributed to a high perception of risk.

\section{Results from study with local schools}

The participants $(\mathrm{N}=62)$ were asked about the basic concepts of nuclear technology and many of them associated the emission of "something" and with the atomic structure. 87\% answered that they knew what radioactivity was, but according to the answers, the majority showed common misconceptions such as: "The notion of radioactivity is linked to nuclear energy", "Radiation in activity", "Energy generated by uranium enrichment".

As observed in both studies, although participants had higher education and were mostly teachers in municipal schools, they did not have more detailed scientific and technological knowledge on the subject. This was also true in the study with the municipality population. However, although they did not understand the discussed technology deeply, they believed that it was beneficial. This perception of beneficial was dependent on the way it would be used and its compliance with the security standards defined globally.

As to this issue, many also cited where they had heard about this subject, with the media being particularly quoted, followed by school, articles and people debating on the subject. It was possible, as well, to observe a negative representation regarding the theme in the answers given, as may be noted in these examples: "Something that damages both man and nature" or "I am aware of the power of destruction, contamination and of medicinal use."

The participants were asked if the school had been sought out by any governmental body to provide further clarification with regard to the implementation of the BMR. It was found that 
the schools had never been approached. This is worrying and highlights the neglected role of education in risk communication processes in the Brazilian nuclear area.

The school is fundamental for social development, as it influences individual growth, promotes social coexistence and reflects on the role of the citizen. Education to be effective must guarantee free and critical participation of learners. The school is an important formal space for scientific dissemination, teachers are opinion makers and are partially responsible for the formation of new citizens especially as education is also a political action (Freire 2001). At the core of the educational process, we have dialogue, which promotes the act of reflecting and acting, as education is a two-way street, promoting exchanges and new knowledge. Such dialogue developed in different phases contributes to the permanent formation of the citizen (Freire 2001, Assis \& De Lima 2011).

Finally, questions were also posed about the role of the school in the context of the BMR implementation and the personal perspective of each participant. Most of them affirmed that the school was of fundamental importance, since, besides instructing, it is responsible for the formation of new citizens and opinions, as well having political importance.

\section{Discussion of results}

To understand the context of the problem addressed in this article, it is necessary to discuss Ulrich Beck's concept of Risk Society (Beck 1992). Beck argues that the Industrial Society, qualified by the production and distribution of development, has been replaced by the Risk Society, in which risks are democratic, affecting nations and social classes without respecting boundaries of any type, especially when these risks appear as new, complex and difficult to predict and control. These aspects may contribute to factors such as lack of knowledge and low trust (Guivant 2001, Queirós et al. 2006), as can be observed in the case of the nuclear field.

Beck asserts that the Risk Society is not apart from globalization because it affects society globally, not distinguishing among social classes, cultures, or individual experiences. It is also noteworthy that even with the high development of science and technology, it is not possible to predict and control all risks or measure all socioenvironmental consequences, especially those unknown and that tend to be irreversible the moment they are revealed Guivant (2001). Under this logic, since we cannot accurately predict the possible problems that may occur due to chemical, nuclear or ecological risks, among others, or see possible compensations for the problems, we would, consequently, trigger an unintentional rejection process. This scenario may be happening in Iperó, since the judgments made by the participants, in general, showed a negative view regarding the facility, worsened by their lack of scientific and technological knowledge, as well as their low involvement with the process of implementation of the BMR, hampering communication between experts and the public.

On the other hand, characterizing risks is not a simple task, since the notion of risk may be ambiguous and transversal to the various problems of society (Perko 2012). Therefore, risk perception and communication studies have been under investigation in different areas of knowledge, seeking to understand the risks in different perspectives and approaches (Queirós et al. 2006). According to Huijts et al. (2012 apud Lienert et al. 2015), this fact occurs mainly because perceived risks and benefits play an important role in the public acceptance of technologies. This is a fundamental factor in the nuclear area, given the events of the 20th 
century that resulted in a negative impact on the perception of nuclear technology.

In general, the participants of the study did not feel secure with the arrival of the BMR in the municipality and related personal insecurity with the possibility of personal harm or socio-environmental impacts (Table I). It was demonstrated that the public hearing held in the municipality did not reach its objectives of clarifying the doubts and concerns of the population and the level of education did not seem to influence decrease in the risk perception of the group studied.

Within this perspective, several studies have contributed to a better understanding of nuclear risk perception and communication. Ferreira \& Soares (2012), for example, presented European enterprises related to the communication failures and their impacts, leading to rejection and fear, as occurred in Hungary in the 1980s. According to the study, it was planned to install a repository of radioactive waste and in spite of the actions organized by those who were responsible for public affairs, international technical arguments and recommendations were raised.
The rejection was such that those responsible did not want to proceed with the project. In 2005 the process of possible implementation was resumed differently from the previous attempt, the population was consulted at all stages of the project and with this procedure, the voting achieved a positive reply from the population that became favourable to the plan and was subsequently inaugurated in 2008.

The study by Pidgeon et al. (2008) showed that the acceptance of nuclear energy as alternative power to the UK energy matrix may increase when the population believes that the nuclear area can contribute towards climate change mitigation, a factor that the authors visualized as relative due to the small number of respondents who prefer nuclear power instead of opting for renewable energy sources. Participants in Pidgeon's research demonstrated an understanding about both climate change matters and nuclear energy as risk-related issues but also expressed "reluctant acceptance" for the use of nuclear energy as an alternative to climate change and this in turn, may indicate complexity in addressing

Table I. Participant's responses regarding issues related to personal risk, collective risk and environmental risk related to the implementation of BMR in the municipality $(\mathrm{N}=198)$.

\begin{tabular}{|c|c|c|c|c|}
\hline & Unsafe & Neutral & Very safe & Negative reply \\
\hline \multirow[t]{2}{*}{ Do you feel safe with the BMR? } & 107 & 28 & 61 & 2 \\
\hline & Absolutely not & Neutral & Yes, certainly & Negative reply \\
\hline $\begin{array}{c}\text { Do you believe the implementation may } \\
\text { cause personal risks? }\end{array}$ & 53 & 39 & 104 & 2 \\
\hline $\begin{array}{c}\text { Do you believe the implementation may } \\
\text { cause risks to Iperó? }\end{array}$ & 41 & 31 & 124 & 2 \\
\hline $\begin{array}{c}\text { Would there be benefits to Brazil with the } \\
\text { arrival of the BMR in Iperó? }\end{array}$ & 66 & 26 & 105 & 1 \\
\hline $\begin{array}{c}\text { Would the BMR be a reason of pride for } \\
\text { you? }\end{array}$ & 101 & 26 & 68 & 3 \\
\hline $\begin{array}{c}\text { Participants evaluation as to the existence } \\
\text { of possible environmental impacts in the } \\
\text { municipality. }\end{array}$ & 68 & 34 & 90 & 6 \\
\hline
\end{tabular}


social and environmental issues concerning the nuclear area.

Yim \& Vaganov (2003) evaluated the effect of the perception of risk and acceptance of risk from nuclear power stations by residents of a city in South Korea. The results presented have shown that there is a negative or positive influence of risk perception on the attitude and acceptance of risk with respect to nuclear power stations depending on the type of associations that individuals establish with the problem. According to the authors, this association may be positive when benefit is perceived, thereby ensuring higher acceptance of risk.

Although these studies were conducted in different countries and contexts, the results obtained showed something in common. It was possible to see in all of them how the public perception related to nuclear technology is a central point in the acceptance of new nuclear installations (Goodfellow et al. 2011). Therefore, public participation is fundamental in socioenvironmental decision-making processes and it is perceived that the absence or negligence in this participation of processes involving the nuclear area causes problems that could be solved more easily with effective risk communication and with educational processes, considering the reality of each country (Huhtala \& Remes 2017, Guimarães 2015).

Renn (2008) states that communication influences the public's ability to analyze how prepared they are to face risks. It should include education to inform, assess and manage risks; training to change attitudes; trust in institutions responsible for risk assessment; and finally, management and involving the public in decision making. As for education, the author highlights that it is a long-term strategy and a two-way street, since the public selects what is interesting and evaluates information according to personal values. To have risk communication combined with education, it is necessary to think about different strategies, such as the development of educational projects, consideration of learning with interactivity and experimentation.

The holding of public hearings can assist in the educational process and in changing the perception of risks on the part of the population, especially when we consider that divergent opinions can be minimized by activities that improve public participation. Manowong \& Ogunlana (2008) points out three important factors for the success of public hearings namely, preparation, discussion and continuous communication.

For effective communication in public hearings, all three factors must be followed with emphasis on a clarity of objectives, use of accessible language as well as being well planned. In the municipality of Iperó, only one public hearing has taken place since the BMR implementation project was announced.

In addition to the results obtained in these exploratory studies, it was evident that there is a lack of knowledge about the subject among participants as well as a high perception of risk. There was also a lack of involvement of the schools in the process. This result is a failed aspect of the risk communication process within the reactor implementation project in the region, primarily because the school may have a close relationship with the community and could help in debates and clarification of doubts of the population. When the school is not involved to contribute to the process of mediation between experts and the community, individuals rely primarily on the media or nongovernmental organizations (NGOs) or any other organizations opposed to nuclear energy. In the case of Iperó, a commission composed of the civil society representatives named the Xô 
Nuclear Coalition ${ }^{2}$ was formed to prevent the work of implementation of the BMR.

On the other hand, there is exaggerated sensationalism currently regarding certain themes in some of the media as a consequence of news industrialization (Manetti et al. 2009). Thus, the fact that the population base their knowledge on the nuclear area only from news without having the minimum scientific and technological knowledge to enable critical reception of what is being transmitted, may contribute significantly in the perception of risk. This is due to the fact that nuclear issues usually appear in news reports when there is a negative event in the area (Manetti 2009). This situation may be occurring in Iperó in relation to the implementation of the BMR, which despite being a benefit has been associated with negative aspects normally communicated in the area.

Education should be present throughout the BMR information process dissemination in the municipality of Iperó and region, as it would be possible to promote debates among the population, contributing to a change in the perception of risks related to the nuclear issue (Paiano 2001). This is directly related to the possible role of schools as agents of social transformation. In the study conducted in the municipality of Iperó by Castro \& Farias (2015), the need to insert the schools of the region into the process of the reactor implementation was evident especially as the locals were not invited directly to participate in discussions about the project, as stated by the majority of the body responsible for schools in the municipality.

However, two central problems can be discussed within the results of the present study that may be interfering with the acceptance of

2 Name of the coalition. "Xô" is a brazilian expression that means "get out". the BMR implementation in the municipality. The first of these is the minimal scientific and technological awareness required for a critical debate on the issue, which brings us back to the subjects raised in the introduction of this paper. The second problem is the lack of encouragement by the BMR experts and project managers for a more effective inclusion of the school in the implementation process.

The solution to these problems involves two dimensions. The first one is related to science education in the country and to the training of teachers regarding nuclear technology. The second dimension refers to the role of education in Brazilian technical projects in the nuclear area, as well as in studies of perception and risk communication.

Therefore, it is not that a reformulation of scientific education is not important, but some pedagogical methodology was not implemented judiciously (Do Nascimento et al. 2010). For example, many teachers did not know how to adapt the booklet experiments, which were imported from other countries or to work with that content. It is also worth mentioning that some experiments did not fit the Brazilian reality. Hence, for effectivere formulation, changes and/or adaptations at all levels of science education are required from elementary school to the undergraduate level. This aspect is allied to the fact that teachers do not receive adequate training to deal with scientific topics, particularly in the nuclear area (Vasconcelos \& Souto 2003).

Training of teachers and insufficient thrust on technical education are not the only difficulties that challenged effective reformulation. Associated with these is the problem of the lack of space in Brazilian school curriculum to address the nuclear issue. There is little content on the same in schools, as discussed by Ayllón et. al (2013). Many teachers do not feel prepared to address the theme and those who do approach it often do so from 
knowledge built up from media information and their respective risk perception thereby neglecting to address the possible benefits of nuclear technology.

The second dimension of the question posed is that in Brazil, research involving the role of education in studies of risk perception and risk communication is still limited and not systematically treated in the country. Coupled with this is the worry that disinformation and its spread among an uninitiated public pose (Wieland et al. 1997, Zarur \& Costa 2012, Castro \& Farias 2015). There have been practical attempts to remedy this with the publication of an Educational Handbook made available on the website of the Comissão Nacional de Energia Nuclear (CNEN) (National Nuclear Energy Commission) or the Centro Regional de Ciências Nucleares do Nordeste (Northeast Regional Nuclear Science Center) (CRCN-NE) project, entitled "CRCN-NE goes to schools", among other actions, when requested by the school.

However, for a significant transformation of the presented scenario, whether in Iperó, in relation to the BMR or in the country, in general, an effective and Continuous Government Policy would be necessary, involving at least the Ministry of Education, the Ministry of Science Technology Innovation and Communication, as well as the Ministry of the Environment, as reflected by Zarur \& Costa (2012). This process should be achieved in an articulated and integrated approach with the states and municipalities, as Brazil is a country with large territorial extension and great cultural diversity.

\section{CONCLUSION}

The implementation of the BMR in the city of Iperó is a multidimensional socio-environmental issue, composed of different social actors within a complex context, i.e., the Brazilian public policy scenario. The subject is very delicate and difficult to approach at the global level as well, given the fear and mistrust that the term "nuclear" arouses in the hearts and minds of people. Despite all the complexity that this problem brings, for which there are no simple solutions, a broad, integrated and continuous vision is necessary so that the presence of the reactor in the municipality of Iperó may not be associated with unnecessary panic.

Public participation should be effective, the population should be informed and institutions and experts should use more accessible terms. Also, environmental education, through formal education, should be permanent, allowing sensationalist information to be evaluated more critically. In order to favor the image of specialists, a few people who are sensitive to the concerns and fears of the public about environmental risks, should attempt to bust damaging myths as well as raise awareness.

Di Giulio et al. (2008) argue that it is essential to think of risk communication strategies to avoid unnecessary panic situations which are often reinforced by the media. In this sense, another idea proposed by the authors is the need for a risk communication plan which establishes a dialogue with the public, seeking to understand how society perceives and experiences risk, as well as social participation in the process of risk management, which are important factors in creating an atmosphere of trust among all the social actors involved.

Finally, Perko (2012), discusses the importance of amplifying the scientific knowledge of the public, which is considered as one of the primary efforts in the process of dealing with risk communication, despite the difficulties that are established in this type of communication strategy.

An investigation into the reasons behind the public rejection of the BMR installation unearthed the importance of the role of the school in the municipality, especially with regard to building awareness about the subject matter. Consequently, both studies highlight, the need to develop educational projects that 
focus on local inhabitants and students of Ipero in order to increase local participation and involvement as well as to enable public opinion to make informed decisions about the reactor installation under different perspectives, such as environmental and social, enabling a more realistic perception of risk.

\section{Acknowledgments}

The authors are especially thankful to Ms. Devika Misra, from Jawaharlal Nehru University, for the language review and insightful contributions in regard to the whole understanding of this article.

\section{REFERENCES}

AQUINO AR \& VIEIRA MMF. 2010. Molibdênio-99, crise e oportunidade. Scientific American Brasil. Disponivel em: <https://scholar.google.com/citations?view_op=view_ci tation\&hl=en\&user=M1maSNEAAAAJ\&citation_for_view= M1maSNEAAAAJ:VOx2b1Wkg3QC>. Acesso em: 01 jul. 2016.

ASSIS GJ \& DE LIMAEE. 2011. FURG. Escola, família e sociedade: Diferentes espaços na construção da cidadania. In: X Congresso Nacional de Educação-EDUCERE.

AYLLÓN RM, FÁVARO DIT \& FARIAS LA. 2013. Representações Sociais de futuros Professores a respeito da Energia Nuclear: possiveis implicações na opinião pública. Internacional Nuclear Atlantic Conference.

BARDIN L. 1994. Análise de conteúdo. Lisboa, Edições Setenta, $226 \mathrm{p}$.

BECK U. 1992. Risk society. Towards a new modernity. Londres, Sage Publications, 272 p.

CASTRO AA \& FARIAS LA. 2015. O papel da educação na diminuição da pecepção de risco e a implementação do reator multipropósito brasileiro: Um estudo de caso. Internacional Nuclear Atlantic Conference.

CONAMA. 1986. Resolução no 01, de 23 de janeiro de 1986. Dispõe sobre critérios básicos e diretrizes gerais para o Relatório de Impacto Ambiental - RIMA. Disponivel em: http://www.mma.gov.br/port/conama/legiabre. cfm?codlegi=23.

DALMORO M \& VIEIRA KM. 2013. Dilemas na construção de escalas Tipo Likert: o número de itens e a disposição influenciam nos resultados? Rev Gestão.org 6(3): 161-174.

DI GIULIO GM, FIGUEIREDO B \& FERREIRA L. 2008. Comunicação de Risco e Mídia: Um debate sobre dois casos brasileiros. Brasil, Anais. IV Encontro nacional da Anppas.
DO NASCIMENTO F, FERNANDES HL \& DE MENDONÇA VM. 2010. O ensino de ciências no Brasil: história, formação de professores e desafios atuais. Rev HISTEDBR on-line 10(39): 225-249.

FERREIRA VVM \& SOARES WA. 2012. InsucesSOS em empreendimentos nucleares devido a falhas em processos de Comunicação Pública. Intercom - Rev Bras Cienc Comun 35(2): 313-329.

FRANTÁL B \& MALÝ J. 2017. Close or renew? Factors affecting local community support for rebuilding nuclear power plants in the Czech Republic. Energy Policy 104: 134-143.

FREIRE P. 2001. Política e Educação. Cortez Editora, São Paulo \& Brasil, $57 \mathrm{p}$

GIL AC. 2002. Como elaborar projetos de pesquisa. Vol. 4. São Paulo, Atlas.

GOODFELLOW MJ, WILLIAMS HR \& AZAPAGIC A. 2011. Nuclear renaissance, public perception and design criteria: An exploratory review. Energy Policy 39(10): 6199-6210.

GUIMARÃES LS. 2015. O desafio da aceitação pública da energia nuclear. R Marit Bras 135(10/12): 115-116.

GUIVANT JS. 2001. A teoria da sociedade de risco de Ulrich Beck: entre o diagnóstico e a profecia. Estud Soc Agric 16: 95-112.

HUHTALA A \& REMES P. 2017. Quantifying the social costs of nuclear energy: Perceived risk of accident at nuclear power plants. Energy Policy 105: 320-331.

HUIJTS NM, MOLIN EJ \& STEG L. 2012. Psychological factors influencing sustainable energy technology acceptance: A review-based comprehensive framework. Renew Sust Energ Rev 16(1): 525-531.

IBGE. 2010. Cidades, Iperó. Available: http://www.cidades. ibge.gov.br/xtras/perfil.php?lang=\&codmun=352100\&sea rch=sao-paulolipero. Access in: March 27th of 2016.

LIENERT P, SUETTERLIN B \& SIEgRIST M. 2015. Public acceptance of the expansion and modification of high-voltage power lines in the context of the energy transition. Energy Policy 87: 573-583.

LIMA RDS, PIMENTEL LCF \& AFONSO JC. 2011. O despertar da radioatividade ao alvorecer do século XX. Quim Nova Esc (Online) 33(2): 93-99.

MANETTI CT. 2009. A imprensa e a percepção de riscos nucleares. Dissertação de mestrado. Instituto de Pesquisa Energéticas e Nucleares. Universidade de São Paulo, São Paulo. (Unpublished).

MANETTI CT, TANIMOTO KS \& HIROMOTO G. 2009. The approach of nuclear related issues by the press. International Nuclear Atlantic Conference.

MANOWONG E \& OGUNLANA SO. 2008. Critical Factors for Successful Public Hearing in Infrastructure Development Projects: A Case Study of the on Nuch Waste Disposal 
Plant Project. Int J Constr Manag 8(1): 37-51. DOI: 10.1080/15623599.2008.10773107.

PAIANO S. 2001. A C\&T como fator estratégico para as atividades nucleares. Parcerias Estrateg 6(10): 13-17.

PERKO T. 2012. Modelling risk perception and risk communication in nuclear emergency management: An interdisciplinary approach. Antwerpen (BE), Universiteit Antwerpen, 203 p.

PIDGEON NF. 1988. Risk assessment and accident analysis. Acta Psychol 68(1-3): 355-368.

PIDGEON NF, LORENZONI I \& POORTINGA W. 2008. Climate change or nuclear power-No thanks! A quantitative study of public perceptions and risk framing in Britain. Glob Environ Change 18(1): 69-85.

QUEIRÓS M, VAZ T \& PALMA P. 2006. Uma reflexão a propósito do risco. Centro de Estudos Geográficos. Faculdade de Letras da Universidade de Lisboa.

RENN O. 2008. Risk governance: coping with uncertainty in a complex world. London, Earthscan, 341 p.

SEADE - SISTEMA ESTADUAL DE ANÁLISE DE DADOS ESTATÍSTICOS. 2016. Informações dos municípios paulistas. Iperó. Available in: http://www.imp.seade.gov.br/frontend/\#/ perfil. Access in January 10th of 2017.

TRACY JL \& ROBINS RW. 2014. Conceptual and empirical strengths of the authentic/hubristic model of pride. Emotion 14(1): 33-37.

TUAN YF. 1980. Topofilia: um estudo percepção, atitudes e valores do meio ambiente. São Paulo, Difel, 124 p.

VASCONCELOS SD \& SOUTO E. 2003. O livro didático de ciências no ensino fundamental proposta de critérios para análise do conteúdo zoológico. Cien Educ (Bauru) 9(1): 93-104.

WIELAND P, STEINHÄUSLER F, XAVIER AM \& UNTERBRUNER U. 1997. Public Perception of Radiation Safety-A Case Study in Brazil. In: Goiânia, Ten Years Later, Proceedings of an International Conference, Organized by CNEN in cooperation with the IAEA. Goiânia, Brazil.

WU Y. 2017. Public acceptance of constructing coastal/ inland nuclear power plants in post-Fukushima China. Energy Policy 101: 484-491.

YIM MS \& VAGANOV PA. 2003. Effects of education on nuclear risk perception and attitude: theory. Prog Nucl Energy 42(2): 221-235.

YIN RK. 2015. Estudo de Caso: Planejamento e Métodos. Bookman editora.

ZARUR RR \& COSTA MAN. 2012. Como melhorar a estratégia de comunicação da questão nuclear no Brasil. Simpósio de Excelência em Gestão de Tecnologia, IX SEGeT.
ZHU W, WEI J \& ZHAO D. 2016. Anti-nuclear behavioral intentions: the role of perceived knowledge, information processing, and risk perception. Energy Policy 88: 168-177.

\section{How to cite}

AYLLÓN RM, CASTRO AA, ROMERO FC, CERQUEIRA LEITE LO \& FARIAS LA. 2022. The Neglected Role of Education in Brazilian Research Regarding Nuclear Theme versus Scientific and Technological Knowledge, Perception and Risk Communication. An Acad Bras Cienc 94: e20200942. DOI 10.1590/0001-3765202220200942.

Manuscript received on June 15, 2020;

accepted for publication on September 15, 2020

\section{RAFAELLA M. AYLLÓN ${ }^{1}$}

https://orcid.org/0000-0002-4566-7533

\section{ALEX A. CASTRO 1}

https://orcid.org/0000-0002-0150-9103

\section{FERNANDA C. ROMERO 1}

https://orcid.org/0000-0002-2864-8592

\section{LUIZ O. CERQUEIRA LEITE}

https://orcid.org/0000-0003-2967-0174

\section{LUCIANA A. FARIAS ${ }^{1}$}

https://orcid.org/0000-0003-3343-3403

${ }^{1}$ Universidade Federal de São Paulo, Instituto de Ciências Ambientais, Químicas e Farmacêuticas, Rua São Nicolau, 210, 09961-400 Diadema, SP, Brazil

${ }^{2}$ Fundação SEADE - Sistema Estadual de Análise de Dados, Av. Prof. Lineu Prestes, 913, 05508-000 São Paulo, SP, Brazil

Correspondence to: Rafaella Menezes Ayllón

E-mail: rafaellayllon@gmail.com

\section{Author contributions}

Each author contributed individually and significantly to the development of the study. Ayllón RM and Farias LA developed the theoretical framework and led the writing of the manuscript, Cerqueira Leite LO and Castro AA contributed with analysis tools for social sciences and data analysis. Romero FC contributed to the English textual review and the final elaboration of the text. Farias LA was also involved in the planning and supervised the work.

\section{(cc) BY}

